\title{
Cost-Related Entrepreneurial Management Practices and Financing of Private Secondary Schools in Rubaga Division - Kampala (Uganda)
}

\author{
Sande Erunao Muwanguzi ${ }^{1}$, Badru Musisi ${ }^{1}$, Gyaviira Musoke Genza ${ }^{1, *}$
}

\section{ARTICLE INFO}

\section{Article History:}

Received 18.12.2018

Received in revised

17.04.2019

Accepted

Available online 01.07.2019

\begin{abstract}
Faced with an increasingly escalating problem of private school financing, the study examined the contribution of existing cost-related entrepreneurial management practices on the financing of private schools in Rubaga Division (Kampala). More specifically, the study considered the contribution of user charges and payment in-kind on school financing. It employed a cross-sectional survey design involving 150 teachers from 15 schools. Results revealed that there is a statistically significant but weak relationship between the two cost-related practices and financing of private schools. The study concluded that prevalent cost-related practices are neither adequate nor equally effective in ensuring a steady flow of financial resources for schools, hence need for both more enterprising alternatives and due diligence. Other recommendations for better financial resource mobilisation and management were made.
\end{abstract}

C IJERE. All rights reserved

Keywords: ${ }^{1}$

Entrepreneurial education management, school financing, resource mobilisation.

\section{INTRODUCTION}

Today one of the most distressing issues in education management in the developing world is that of educational cost and finance (World Bank, 2002). More than any other problem, it is this problem that explains the closure of most private schools, as well as students' school dropout in Uganda (Wambede \& Mukaaya, 2017). Relatedly, although not all parents have the money (cash) to meet their children's educational obligations; school financing using money remains the main method of paying fees in private schools (Powell, 2008; World Bank, 2002). It is therefore urgent to come up with other cost-related entrepreneurial measures to salvage schools in general and parents in particular (Psachoroplous, 1985).

However, only a few private schools seem to offer such alternative arrangements that offset monetary spending (Mugimu, 2016) to enable them (schools) to continuously deliver quality education in quantity. Yet many private secondary schools are struggling to survive financially. For example, Wambede et al. (2017) indicates that in Manafwa District alone (Eastern Uganda), over 100 private schools have been closed recently over failure to provide adequately equipped libraries and laboratories; other schools have ended up closing the School Term before the set date due to high costs of operation. Perhaps adoption of entrepreneurial cost-related strategies such as introduction of user charges could help to alleviate the situation (World Bank, 2003). Unless this is done, problems of persistent financial deficits may continue unabated; and, coupled with school closures, many learners may be left out.

Yet only a handful of studies have focused on this problem of entrepreneurial innovations in school finance, and the interest of most of these was either in public schools or in the basic (primary) level of education, leaving private secondary schools largely unstudied (Mugimu, 2016). The current study sought to fill this gap by examining the contribution of selected cost-related entrepreneurial innovations on the financing of private secondary schools in Rubaga Division (Kampala-Uganda). The study had two (2) specific objectives: To find out:-

i. The contribution of user fees on the financing of private secondary schools.

ii. The contribution of payment in-kind on the financing of private secondary schools.

\section{STUDY BACKGROUND}

In Africa, the introduction of both private education in general and private schools in particular was due to an excessive demand for education, since the 1970s (Lessbille, 1999). By the mid-1980s, most

\footnotetext{
*Corresponding e-mail: musoke@cees.mak.ac.ug; orcid.org/0000-0002-5927-8731

${ }^{1}$ School of Education, College of Education \& External Studies, Makerere University, Uganda
} 
governments in developing countries were already overwhelmed by the increasing student numbers, hence resorting to privatisation of education to sustain education expansion (Ssekamwa, 2000; Lessbille, 1999). However, most of these private schools operated under poor conditions (Curtis \& Machacek, 2016). Therefore cost-sharing was introduced, where parents and the community shared the burden. To further drive costs down - and thus to offer an affordable education - schools began devising certain costminimising strategies, such as using students' own labour instead of outsourcing labour (Curtis et al., 2016). Later, it was the Jomtien (Thailand) declaration of "Education for All" (EFA) (in 1990) that leapfrogged the cause of innovative education financing (World Bank, 2003). For otherwise how were developing countries like Uganda to educate every child except, perhaps, also by thinking outside the box? Such "out-of-the-box thinking" (Rina, Murtini \& Indriayu, 2018) is what the current study refers to as "cost-related entrepreneurial practices".

"Entrepreneurship" is the process of discovering new ways of combining resources for greater value (Sobel, 2008). In the context of education, entrepreneurship implies "rejuvenation" within schools (Fuller, 1990). It involves both a vision for a better way of doing things (innovations), and thinking beyond the constraints of current rules and resources (Rina et al., 2018; Burnett, 2010; Lessbile, 1999). For the current study, entrepreneurship meant the process by which school leadership (administrators and managers) devises and/or adopts cost-minimising strategies. In this case, directors of schools, school administrators (like the Head teacher) and managers (Boards of Governors) are the entrepreneurs. They may imitate ("copy") what other schools are doing and try to fit it in their own settings (Atilio, 2017). For school financing, an example of an entrepreneurial practice/innovation is the charging of user fees, whereby "extra" school services (e.g. for computer use and study tours) are paid for separately (Amaliawati, Martono \& Indrawati, 2019; Olagboye, 2004; Burnett, 2010).

As Drucker (1985) contends, an "entrepreneurial innovation" is one arising out of "creative imitation"; it takes place whenever an enterprising person ("imitator") recognises how some devise or process can be applied, used or sold in his/her particular market better than the original creators thought. These conceptualisations were further illumined and justified by Genza and Musisi (2018)'s depiction of "educational entrepreneurship" as "the innovative application of smart strategies to the management of educational institutions in a way that can result in the reorganisation of an entire education system to meet society's changing needs in a sustainable manner" (p. 11).

The current study was guided by the Schumpeterian opportunity discovery theory of entrepreneurship (Genza et al., 2018). The theory focuses on the existence, discovery and exploitation of opportunities and the influence of certain individuals - "entrepreneurs" - in that process (Amaliawati et al., 2019; Rina et al., 2018; Shane \& Venkataraman, 2000; Shane, 2003). The theory conceives of an entrepreneur as an important force in an institution that implements change by introducing new methods of production through a process of discovery. It is the entrepreneur, such as head teacher or director of school, who identifies how these new combinations can be applied in production (Marz, 1991). The current study further assumes that private secondary school administrators and managers are entrepreneurially innovative (Dezembro, Sharon \& Jay, 2007) - they exploit opportunities existing around them to improve on their schools' financial standing. They constantly search for cost-minimising strategies used by other schools and adopt them to their own settings, without losing sight of national educational goals. However, it is not so clear what kind of "cost-minimising strategies" are prevalent in private secondary schools; and, secondly, what contribution these strategies succeed in making on the financing of private secondary schools.

\section{REVIEW OF RELATED LITERATURE}

The study pivoted around two kinds of potential entrepreneurial cost-related practices; namely, payment of user fees and payment in kind. Available studies conceptualised "user fees" differently. For example, Lagarde and Palmer (2008) had technically viewed it in terms of two categories; namely, (1) Risksharing, whereby payment is made at the point of service use (for example parents paying construction fees when construction is actually going on at school); and (2) Where there is no risk-sharing. They defined "risk sharing" as any system which allows payers to share some of the financial risks associated with a particular user population (Lagarde et al., 2008). Lagarde et al. (2008) further categorised user fees in terms of being "official" or "unofficial". However, they contended that the risk of change in cost of equipment to be purchased using these official and unofficial fees does not affect the payers (parents). 
Similarly, on absence of risk-sharing, Adela (2013) contended that service providers agree to adhere to fixed fee schedules even when there is an increase in the cost of purchase of equipment and only stand a chance to survive if they use other cost containment measures but not extending the cost to the payers. However, Adela's (2013) study only stated the expected; it did not go as far as reporting whether actually things work out in the real world. The study was also done basing on a Jamaican context, leaving the African setting unattended to.

Other pertinent studies on user fees were the Word Bank $(2001,2006)$ and the Uganda Bureau of Statistics [UBOS] (2004). The two revealed that apart from paying tuition fees, parents separately pay for exercise books, text books, meals, clothing (school uniform), transportation, PTA/community contributions, and other school-based activities such as exams. Of these, the current study concentrated on only those user fees that are more likely to help schools to become more cost-effective, as well as remaining user friendly to low income parents.

More specifically, the current study was interested in finding out the effect of user fees on school financing. Studies carried out in the health sector in Zambia, Senegal and Uganda indicated that user fees were so helpful in financing hospitals that their eventual abolition resulted in partial closure of some units since there was no money for paying staff (Witter et al., 2010; Masiye et al., 2008; Nabyonga-orem et al., 2008; WHO, 2005). For education, the elimination of private user charges, followed by a $13.6 \%$ increase in government spending on education in Uganda at the introduction of UPE (in 1997) (Burnett, 2004), is reported to have resulted in decline in education quality (Deininger, 2003). This implies that during the preUPE era, user charges had played a positive role in school financing; once schools did away with the fees, their financial functioning was negatively affected. Thus, even when government takes over overheads, the abolition of user fees does not necessarily improve access to services, since there are indirect costs that remain uncaptured (Rutebemberwa et al., 2009; Burnham et al., 2004). However, the studies by Witter et al., (2010), Masiye et al., (2008) and Nabyonga-orem et al., (2008) were carried out in the context of developed countries and, moreover, in health institutions; yet the dynamics of user charges vary depending on the sector in which they are applied, and on the socio-economic and geographical setup in place; hence need for the current study.

On the issue of payment in-kind, available studies revealed that some countries like Nepal attempted to overcome schools' financial woes by allowing parents to pay in kind rather than in cash (Merman, 1980), for example by providing schools with firewood or foodstuffs like beans. In this regard, Zymelman (1973) contends that payment in kind has a great potential as an educational financing method because it provides extra readymade resources. Sometimes it is members of the local community that provide their own labour by making bricks, physically constructing classrooms, and/or donating local materials such as tree poles. This was the case with Kenya's Harambee schools. Also in Malawi, payment in kind was used in construction of primary school buildings and its contribution is estimated to have cost a third of the amount it took to construct conventional buildings (Zymelman, 1973). However, Zymelman (1973)'s study was considered by the current study not only to be too outdated to give valid evidence on current issues, but also to have targeted public schools, leaving the situation in private secondary schools largely unknown.

More on payment in-kind mechanisms, research indicated that some schools require parents to provide physical items such as text books and brooms, rather than pay for them in cash (Merman, 1980). Citing evidence from Trinidad and Tobago, Panama, Honduras and Cuba, Brodersohn (1978) concluded that between 25 and 50 percent of the operating and maintenance costs of a school were sometimes financed by such provision of goods and services in kind. However, Merman (1980)'s and Brodersohn (1978)'s studies were found to be limited by, among others, being localised in Latin American rural settings, whose dynamics were thought to be different from those of urban African schools in Kampala (Uganda). Concerning Africa, Gahvari (2008) reported that mechanisms of payment in kind were available in both public schools and hospitals in Uganda, although their contribution to institutional finance remained largely unknown. Yet Gahvari (2008) remained silent on the situation in private schools.

Other studies provided cases of payment in kind based on mainstream business institutions, where taxes were paid in terms of physical goods (Kapsoonkim \& Sungmanyoon, 2017; Ethan \& Lockwood, 2013). Kapsoonkim et al. (2017) reported that in South Korea, tax payment in kind drove buyers to lower in purchasing price in the open market since taxes paid for in kind tended to be lower than their monetary counterparts; the open market selling price to the end user also became very low. Similarly, Ethan and 
Lockwood (2013) contended that tax payment in kind potentially had offsetting benefits such as improving consumption to intended users, and increasing the efficiency of the tax system. Yet Marino (2003) disagreed with the above two studies, arguing that the in-kind payment system involves wage discrimination in tax collection. This might imply that, even in schools, those who provide payment in kind face discrimination both in form of being cheated as well as being served last. Moreover, Kapsoonkim et al. (2017), Ethan et al. (2013) and Marino (2003) limited themselves to mainstream business taxation, leaving the problem of costrelated practices vis-à-vis financing of private secondary schools unexamined.

\section{METHODOLOGY}

The study was carried out using a cross-sectional survey design, and a sample size of 150 teachers (out of 250), arrived at using Krejcie and Morgan (1970). Most of the teachers (82; 55\%) were male; 68 (45\%) were female. Whereas 35\% (53) were full-time teachers; $65 \%$ (97) were part-time teachers. However, even these part-timers were found to be conversant with the school financing realities of their respective institutions. The study involved also other respondents, namely, ten head teachers and ten school bursars for more focused information. Schools, teachers and other respondents were selected using stratified random, convenience and purposive sampling techniques. Non-teacher respondents sampled were school bursars and head teachers. Questionnaire, interview guide, FGD and observation checklist were the primary data collection instruments employed. Data was analysed using both descriptive and inferential statistics, as well as thematic analysis. Both internal and external validity were catered for.

The study was conducted in ten (10) private secondary schools in Rubaga Division. This Division is one of the five divisions that make up Kampala City. The Division was chosen because most of the studies carried out (in other countries) were in rural areas, hence need for a study localised in an urban setting. Secondly, Rubaga had a variety of private secondary schools, such as the private-for-profit ("private squared" - 7 schools) and the private religious schools (3 schools).

\section{FINDINGS AND DISCUSSIONS}

\section{User fees and financing of private secondary schools}

By its first objective, the study sought to find out the contribution of user fees to the financing of private secondary schools. The first question was whether students were being charged specific user fees. Results are as in Table 1.

Table 1: Schools Charging Specific User Fees

\begin{tabular}{lccc}
\cline { 1 - 3 } RESPONSE & f & \% & \multirow{2}{*}{} \\
\cline { 1 - 3 } Highly Agree & 44 & 29.3 & \\
\cline { 1 - 3 } Agree & 29 & 19.3 & $\mathbf{4 8 . 6}$ \\
\cline { 1 - 3 } Don't Know & 28 & 18.7 & 18.7 \\
\hline Disagree & 21 & 14.0 & \\
\cline { 1 - 3 } Highly Disagree & 28 & 18.7 & 32.7 \\
\cline { 1 - 3 } TOTAL & $\mathbf{1 5 0}$ & $\mathbf{1 0 0}$ & $\mathbf{1 0 0}$ \\
\hline
\end{tabular}

Table 1 indicates that $48.6 \%$ of the respondents agreed that their schools had specific user fees payable by students. This means that for the majority of private schools tuition fees charged is not enough to cater for all the requirements needed in the school, hence "some other" specific user fees to cater for such requirements. These results are in line with UNEB (2004) and World Bank (2006)'s findings which highlight charges for school uniform, texts books and other school-based activities as potential extra school financing mechanisms.

During interview and FGD, respondents strongly argued that user fees are part and partial of every school because without them, many school programmes are likely to fail.

A school cannot easily be run purely on only school tuition fees unless there is a calculation of all the money which would be charged as user fees and is put on tuition fees, which however may look a big sum to parents...Every service provided to students goes with a cost which has to be paid for. We ask candidates to pay facilitation fee, and even during Ramadhan we ask for such fees as well as other fees like laboratory fee, library fee, examinations fee (Head teacher's interview).

Similarly, one bursar reported that; 
Yes, our students are required to pay for some other charges apart from tuition fees. For example they pay for their mock and final exams (UNEB) separately, they pay for medical care, hair trimming, and even academic tours (Bursar's interview).

However, respondents highlighted also the existence of competition between user fee and tuition fee payment; where many kinds of user fees are charged, the "user fee strategy" easily turns counterproductive as little direct tuition ends up being paid by parents.

You know the kind of parents we have; they pay [tuition] in very small instalments. When we put many user fees, many parents don't pay any tuition at all on school opening day. So what we do, we at least enforce the payment of user fees on time such that we can use income from that to run even other urgent school activities (Bursar's interview).

Thus, if not well calculated, the charging of user fees could jeopardise the effective financing of a school. This is in conformity with Yates (2009)'s health sector findings, where excessive user fees tended to reduce health services accessibility to many people. The finding also rhymes with Aryel (2002)'s study that user fees can easily result in low school enrolment, as learners from low income families may end up disappearing from school due to failure to pay these extra fees.

After establishing the existence of user fees in schools, the study sought to find out what specific kind/form of user fees were prevalent in Rubaga Division, as summarised in Table 2.

Table 2: Forms of User Fees Charged by Private Secondary Schools

\begin{tabular}{llll} 
& Form of User Fee & f & \% \\
\hline $\mathbf{1}$ & School uniform fee & 94 & 62.7 \\
\hline $\mathbf{2}$ & Medical fee & 92 & 61.3 \\
\hline $\mathbf{3}$ & Identity card fee & 91 & 60.6 \\
\hline $\mathbf{4}$ & Admission fee & 86 & 57.3 \\
\hline $\mathbf{5}$ & Study trips fee & 86 & 57.3 \\
\hline $\mathbf{6}$ & Lunch fee & 83 & 55.3 \\
\hline $\mathbf{7}$ & Hair trimming fee & 71 & 43.3 \\
\hline
\end{tabular}

Table 2 reveals that the three most prevailing forms of user fees are uniform fee, medical fee and identity card fee, followed by admission and study trip fees. These being services necessary for every student, many schools actually get good extra money out of user fees. However, the taxonomy of user fees in Table 3 largely disagrees with that of Boyle et al. (2002)'s study, where user fees were categorised as: telecommunication, infrastructures and teachers' funeral. Boyle et al. (2002)'s forms are quite foreign to the Ugandan private school setting.

Individual findings on different user fees (e.g. construction fee, examination fee \& meal fees) were then put together and correlated with the financing of private secondary schools. Results are presented in Table 3.

Table 3: Correlation of User Fees with Financing of Private Secondary Schools

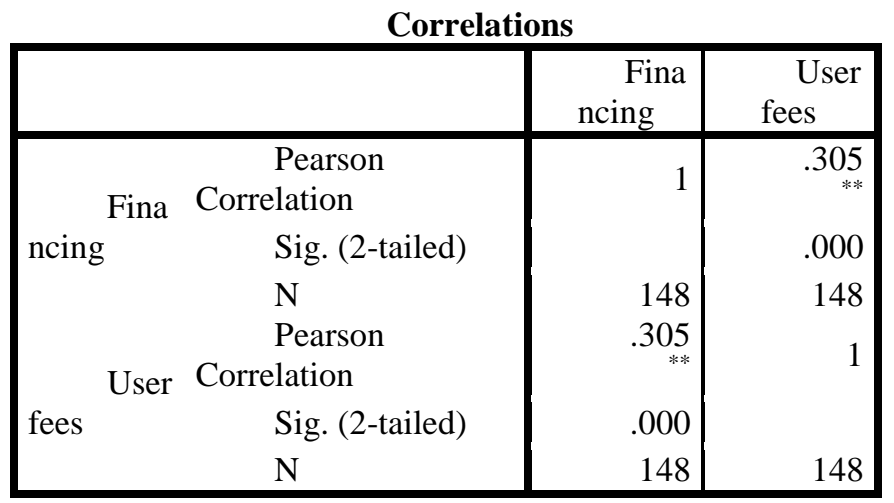


**. Correlation is significant at the 0.01 level (2-tailed).

Table 3 reveals that there is a significant relationship between (charging of) user fees and financing of private schools. The relationship is positive, implying that the more of user fees the more effective the financing of private schools. However, though positive, the relationship is low ( $r=0.305$; about $31 \%)$, meaning that there is need to base financing not only on user fees but also on other cost-related measures. Otherwise, alone on their own, user fees provide insufficient financial support to private schools. This conclusion agrees with Adams and Harnett (1996), as well as Oxfam (2001), that user fees contribute only a fraction of education financing. The findings also agree with Hillman and Jenkner (2002), whose study in Kenya showed that user fees succeeded in financing only $34 \%$ of the cost for primary education, and about $20 \%$ for higher education, with the balance being financed through public (government) spending.

\section{Payment in kind and financing of private secondary schools}

By this second objective, teachers were first asked to indicate whether payment in kind (in terms of such items as beans and reams of paper) was common in their schools (Table 4).

Table 4: Schools Allowing Payment in Kind

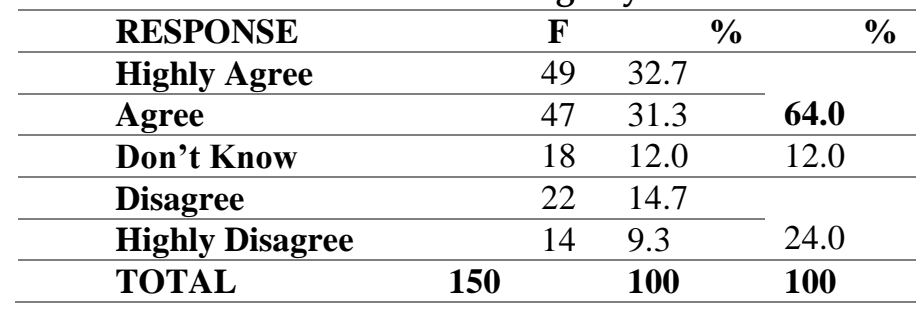

Table 4 reveals that most of the respondents (64\%) agreed that payment in kind was common in their schools. This means that schools do not deter parents from clearing fees in kind. It also means that schools do not need to spend more on purchasing of certain items already brought in kind. This is in line with Merman (1980) that, in rural primary schools, parents pay only some school fees in monetary terms, otherwise pay the rest in kind in terms of text books, brooms and food. The findings also agree with Brodersohn (1978)'s findings (in Trinidad and Tobago, the Dominican republic, Panama, Honduras and Cuba) that between 25 and 50 percent of operating and maintenance costs of a school are financed by provision of goods and services in kind.

One wonders what these goods really are that are paid in kind in Rubaga Division. Teachers revealed these, as indicated in Table 5.

Table 5: Items Paid in Kind among Private Secondary Schools

\begin{tabular}{llcc}
\hline & Kind of Good & F & \% \\
\hline $\mathbf{1}$ & Reams of paper & 78 & 52.0 \\
\hline $\mathbf{2}$ & Toilet papers & 75 & 50.0 \\
\hline $\mathbf{3}$ & Brooms & 72 & 48.0 \\
\hline $\mathbf{4}$ & Brushes/squeezers & 42 & 28.0 \\
\hline $\mathbf{5}$ & Beans & 28 & 18.7 \\
\hline $\mathbf{6}$ & Maize flour & 26 & 17.3 \\
\hline $\mathbf{7}$ & Text books & 22 & 14.7 \\
\hline
\end{tabular}

Table 5 indicates that reams of paper, toilet paper and brooms are the three most common items brought to school in kind. Although the study setting was urban, also food items (such as beans and maize flour) are also sometimes paid in kind, though rarely. These findings mean that there are many items that private schools receive in kind today, hence warding off costs (e.g. time \& money) they would have to incur going to purchase those items. Thus, the more students bring assets in kind, the more schools save - ceteris paribus. This concurs with Zymelman (1973) that payment in kind has a great potential of saving school resources.

However, interviews and FGD revealed that not any kinds of goods are accepted in kind. Respondents explained that acceptance of physical items by their schools depended on whether those items appeared to be "profitable" to their schools or not; 
We give them [parents] room to express their concern [on payment in kind]. Once we find out that their alternative mode of goods is profitable to the school, we can let them go ahead (Head teachers; FGD).

Similarly, one bursar opined that there are many challenges associated with physical items, such as provision of non-uniform and poor quality items.

Some clients bring us poor quality duplicating reams of papers as well as poor brooms that cannot serve us to the expectation (School Bursar Interview).

On the side of parents, it was also discovered that some of them like paying in kind just to avoid paying bank charges, especially for low income parents that clear fees in many instalments. This agrees with Anna (2014) that school payments made in kind render themselves free from certain tax levies and bank charges.

Findings from individual user fees items were eventually correlated with the financing of private secondary schools, as in Table 6.

Table 6: Correlation of Payment in Kind and Financing of Private Secondary Schools

\begin{tabular}{|c|c|c|c|}
\hline \multicolumn{4}{|c|}{ Correlations } \\
\hline & & Financing & Kind \\
\hline \multirow{3}{*}{ Financing } & $\begin{array}{c}\text { Pearson } \\
\text { Correlation }\end{array}$ & 1 & $.294^{* *}$ \\
\hline & $\begin{array}{l}\text { Sig. (2- } \\
\text { tailed) }\end{array}$ & & .000 \\
\hline & $\mathrm{N}$ & 148 & 148 \\
\hline \multirow{3}{*}{ Kind } & $\begin{array}{l}\text { Pearson } \\
\text { Correlation }\end{array}$ & $.294^{* *}$ & 1 \\
\hline & $\begin{array}{l}\text { Sig. } \\
\text { tailed) }\end{array}$ & .000 & \\
\hline & $\mathrm{N}$ & 148 & 148 \\
\hline
\end{tabular}

**. Correlation is significant at the 0.01 level (2-tailed).

Table 6 indicates that there is a significant relationship between payment in kind and financing of private schools. The relationship is positive, implying that the more of payment in kind the more the effective financing of private schools. However, though positive, also here the relationship is low $(r=0.294$; about $29 \%$ ), implying that payment in kind alone cannot do miracles; there is need of adopting other costrelated measures. Thus, though the influence of payment in kind on financing of private schools is significant, this form of payment is inadequate in ensuring strongly financed private schools. It needs to be supplemented by other forms such as payment in monetary terms. This disagrees with such studies as Nyaga (2005), Chabari (2010) and Nyaga 2005), which overrated the potential of payment in kind in improving on school financing.

\section{CONCLUSIONS}

The study concludes that, first, user fee charges represent an innovative cost-minimising entrepreneurial practice that is not only prevalent but also viable. User fees enable schools to receive some immediate payments for immediate liquidity at the beginning of each School Term, also when tuition fees are not yet paid in bulk. Otherwise tuition fees charged by most schools are insufficient to enable the schools to sustainably offer quality education in quantity. Thus, the move of asking parents to pay certain fees separately (from tuition) is indeed innovative and entrepreneurial. However, user fees do not solely stand to create effective private school financing since they cannot yield all the funds needed in the school.

Secondly, however helpful payment in kind may be in financing private schools, it can only remain significant if it is properly equated with monetary payments such that it creates no more need to spend on those assets brought to school in kind. This means that payment in kind ought to be well calculated to avoid certain challenges associated with it, such as challenges of uniformity and quality of items brought physically. 
With regard to the Schumpeterian opportunity discovery theory that informed the study, the study concludes that the theory does not go far in explaining the innovative cost-related entrepreneurial management practices adopted by private secondary schools. It is true that many schools are smartly trying to borrow, devise and/or implement innovative cost-related measures using any opportunities existing around them; however, schools are not doing this radically through Schumpeter's "disruptive innovations" (big game-changing innovations) (Jack, 2013). Rather, schools are doing so incrementally (or "conservatively") - by seeking competitive advantage largely through smart adoptions of new practices in small bits - a trend of entrepreneurship that is more Kirznerian than Schumpeterian. Schools being conservative educational institutions (Genza et al., 2018), the study concludes that it is incremental innovative cost-minimising practices that are easier to sell in private schools - because they are less disruptive and thus less controversial to different stakeholders.

\section{RECOMMENDATIONS}

The study makes the following recommendations;

First, to avoid inadequacy of funds, schools should continue charging different user fees to compliment tuition fees. However, user fees should not be so many as to confound parents. Secondly, there should be clear communication as to when to pay what fees to avoid late payments due to poor information.

Secondly, schools should accept substitution of fees with physical items only after properly equating them (physical items) with their monetary counterparts to avoid quality challenges.

Finally, for future research, the study recommends more comprehensive examination of certain pertinent issues that were only hinted upon in this study. One of them is how much of a gain or a loss payment in-kind is to the different parties involved - students, parents and school administration. A practice may be innovative and cost-minimising - and thus making a positive contribution to school financing - but at what cost to the other parties (students \& parents)? Is life not more than making profit? These are issues for further research.

However, this study is considered limited by both its scope (only private secondary schools) and its design (cross-sectional survey). Perhaps a longitudinal study, with some schools in a control group and others in a study group, could help to measure realities of change over a period of about five to ten years. Nevertheless, the current study remains significant particularly for its exemplification of scholarly work on the often neglected problem of entrepreneurial education management vis-à-vis school finance.

\section{REFERENCES}

Adebambo, K.A. (2007).Vocational and technical education and training. Ibadan Gabesther Educational publishers.

Adella, C. (2013). The abolition of fees in the Jamaican public health system: Impact on access, care provided and the work of the professional nurse. Unpublished PhD thesis of Victoria University, Wellington.

Amaliawati, S., Martono, T. \& Indrawati, C. D. S. (2019). The influence of entrepreneurship education on the business performance through entrepreneurial intention. International Journal of Educational Research Review, 4(2), 162-171.

Amin, E.M. (2005). Social Science research: Conception, methodology and analysis. Kampala: Makerere University Press.

Ansah, E.K, Narh-Bana .S, Asiamoh .S, Dzordzordzi .V, Blantey .K, Dickson .K, and Whitty C.J.M. (2009). Effects of removing direct payment for health care on utilisation and health outcomes in Chananian children: A randomised controlled trial. Plos med, 6(1), 48-58. Retrieved from http://search.proquest.com/docview/66861174

Anthony M.M, (2003). In-kind payment as a compensation strategy. Los Angeles: University of Southern California. 
Arye, L.H,\& Eve .J. (2002). User payments for Basic Education in Low-income countries. IMF working paper.

Babble, E.R. (2010). The practice of social research (12 ${ }^{\text {th }}$ Ed.). Belmont: Wadsworth Cengage Learning.

Bailey, D.K. (1994). Methods of social science research (4th Ed.). London: Macmillan Publishers:.

Bello, Z.A. (2002). Student financing in Nigeria: paper presented at the National Summit of higher education, Abuja. Federal Ministry of Education, March 10th - 16th.

Bikas, C. Sanyal \& Michnelamartin.(2006). Financing higher education: International perspectives.

Bitran, R. and Giedion .U. (2002). Waivers and exemptions for health services in developing countries. Washington D.C: World Bank.

Burnham, G.M, Pariyo .G, Galiwango E.J. \&Wabwire-Mangen, F. (2004). Discontinuation of cost sharing in Uganda. Bulletin of the World Health Oraganisation, 82(3), 187-195.

Castle, E.B. (1966). Growing up in East Africa. London: Oxford University Press.

Cume, J. \& Gahvari .F. (2008). Transfers in cash and in-kind: Theory meets that data. Journal of Economic literature, V6 (2); 333-383.

Dauber, S.L \& Epstein J.L. (1993). Parents attitudes and practices of involvement in inner-city elementary and middle schools, families and schools in a pluralistic society. New York: Suny Press.

Denscombe, M. (2007). The Good research guide for small scale social research projects (3rd Ed.). Berkshire: Open University Press.

Dezembro, S. A.A. \& Jay B.B, (2007). Discovery and creation: Alternative theories of entrepreneurial action.

Drucker, P.F. (1985). Innovation and entrepreneurship. Newyork: Harper Business.

Eccles, J. (2003). Extracurricular activities and adolescent development. Journal of social issues, 59(4), 865-889.

Enon, J.C. (1998). Educational research, statistics and measurement. Kampala: University Press.

Ethan M.J.L and Lockwood L.M. (2013). Costs and benefits of in-kind transfers: The case of Medicaid home care benefits. Michigan: University of Michigan.

Fredrick, M. H. (2006). New schools venture fund: Realities, challenges, possibilities.

Gardener, M. Roth .J. \&Brooks-Gunn. J. (2008). Adolescents' participation in organised activities and developmental success 2 and 8 years after high school: Do sponsorship, duration, and intensity matter? Developmental psychology, 44(3), 814-830.

Genza, G. M. and Musisi, B. (2018). Educational Entrepreneurship (EE): Delineating the Domain and Highlighting its Importance and Feasibility in Educational Management in Uganda. American Journal of Educational Research, Vol. 6, no. 1 (2018): 9-17. doi: 10.12691/education-6-1-2.

Genza, G.M., Kobusingye .P. a\& Mukokoma .M. (2016). The contribution of student services entrepreneurial ventures to secondary school teachers' standards of living (SOL) in Kalungu District (Uganda). Asian Journal of Management Sciences and Economics, Vol. 3, No. 1, 2016; pp. 1-14.

Gilman. R. (2004). Structured extracurricular activities among adolescent findings and implications for school psychologists. Psychology in the schools, 41(1); n.p

Green, P.E, Tull D.S \& Albaum G. (2000). Research for marketing decisions. New Delhi: Prentice Hall.

Hornby, A.S, (1948). Oxford advanced learners Dictionary (7th Ed.): Oxford University press.

Jack, L. (2013). Innovation in the schoolhouse: Entrepreneurial leadership in education. Maryland: Rowman\& Littlefield.

James, E. (1991). Private finance and management of education in developing countries: major policy and research issues. Paris. UNESCO/IIEP.

Jenkner, E. \& Hillman, A. L. (2002). User payments for basic education in Llow-income countries; IMF working paper. Accessed on 20th March, 2018 from https://www.imf.org/en/Publications/ WP/Issues/2016/12/30/User-Payments-for-Basic-Education-in-Low-Income-Countries-16133.

Jodi Beggs, (2017). Introducing to cost minimisation in Private schools and Institutions Department. n.p

Kaplan, B. \& Duchon, D. (1988). Combining qualitative and quantitative approaches in information systems research. MIS Quarterly, 12(4): 571-586.

Kapsoonkim \& Sungmanyoon (2017). Tax payer's perception to tax payment in kind system in support of SMEs' sustainability: Case of the South Korean Government's valuation of unlisted stocks. (http://creativecommons.org/licenses/by14.01). Journal on $26^{\text {th }}$ August 2017.

Kayode, M.O. (1972). Towards a principle of financial allocation in educational planning. West African journal of Education, XVI (1). 
Kexu, D.B.E, Kadama .P, Nabyonga. J, Ogwang, P.O, and Aguilar A.M. (2005). The elimination of user fees in Uganda: Impact on utilisation and catastrophic health expenditures. Geneva: World Health Organisation.

Kim, S. \& Taylor .K. (2008). Rethinking Alternative Education to break the cycle of Educational inequality and inequality. Journal of Educational Research, 101 (4), 207 - 219.

Kingston, J. (2009). Annual report 2007. Kampala: Ministry of Health in Uganda.

Konings, Keren .D, Mario .J.V, Saskia .B.G, \&Memenboer .J.J.V, (2007). Participatory design in secondary education: Is it a good idea? Students' and teachers' opinions on its desirability and feasibility. Educational studies 33(4): 445-67.

Kothari, C.R. (2004). Research methodology: Methods and techniques (2nd edition). Newage International CPD Ltd.

Krejcie, R.V. \& Morgan, D.W. (1970). Determining sample size for research activities: Educational and Psychological measurement. Retrieved from http://home.kku.ac.th/.../KrejcieandMorganarticle.pdf(11-9-2014)

Kwong, J. 1997. The re- emergence of private schools in socialist china. Comparative education review vol.41. No 3 pp. 244-259.

Lagarde, M. \& Palmer .N. (2008). The impact of user fees on health service utilisation in low and middleincome countries: How strong is the evidence? Bulletin of the WHO, 86(11), 839-848.

Le Thanhkhoi (ed) (1971). L'enseignement en Afriquetropicale.Groupe de recherché de L'IEDES. Paris: presses universitaires de France.

Masiye, F, Chitah .B.M, Chanda .P, \& Simeo .F. (2008). Removal of user fees at primary health care facilities in Zambia: A case study of the effects on utilisation and quality of care. University of Zambia and University of Cape Town.

McCarthy, J.D.\& Mayer, N. Zald (1977): Resource mobilisation and social movements: A partial theory. The American journal of sociology, vol. 82; pp. 123-185.

Miles, M. and Huberman, A.M. (1994). Qualitative data analysis: an expanded source. Thousznds Oaks; sage publications.

MOE \& S. (2008). Guidelines for establishing licensing, registering and classification of private schools/ institutions in Uganda.

Moorad, F. (1997). Community financing of education in Botswana. Paper presented at pan-Africa seminar on "The financing and financial management of education in Africa". Dakar 12-14 October 1997

Mukudi, E. (2004). International review of education: The effects of user-fee policy on attendance rates among Kenyan elementary school children. Netherlands: Kluwer Academic Publishers.

Nabyonga, J, Oryem .J, Karamagi .H, Atuyambe .L, Bagenda .F, Okuonzi S.A, \& Walker .O. (2008). Maintaining quality of health services after abolition of user fees: A Uganda case study. BMC Health services research, 8, 102-111.

Ngware, M.W. (2007). Financing secondary Education in Kenya: Cost reduction and financing options. KPPRA, Nairobi.

Nicholas, B. (2010). Strategies for financing of education. Global View, pp7-15.

Niimoi, T. \& Leslie, C.H. (2008).The financing and outcomes of Education in Ghana.

Nikki, W. (2009). Impact of extracurricular activities on students. University of Wisconsin-stout.

Norden, A. (2014). Payment types and participation in payment for ecosystem services programs: Stated preferences of land owners. Working papers in Economics, No. 59: University of Gothenburg.

Oduogi, A.A (2004). Income generating activities in secondary schools: Med thesis, Kenyatta University Kenya.

Ojwang, J. A., Genevieve, W. \& Muriithi, M. (2016). Financial resource mobilisation strategies and internal efficiency of public secondary schools in Rachuonyo South Sub-county, Homabay County. Kenya Journal of Educational Planning , Economics and Management,10(1).

Oslon, C.A. (2008). Can music education help at-risk students? Teaching music, 16(3).

Psacharopoulos, G. \& Woodhall, M. (1997). Education for development: An analysis of investment choices

Raja, B.K. (2006). Implementation of free Basic Education policy. The World Bank, Washington D.C, USA.

Raja, B.K. \& Burnett .N. (2004). User fees in primary education. DC: World Bank

Reeves, D.B. (2008). The Extracurricular advantage. Education leadership, 86-87.

Rina,L., Murtini,W., \& Indriayu, M. (2018). Establishment of entrepreneurial character in the foundation based school system through project based learning. International Journal of Educational Research Review, 3(4), 128-140. 
Robertson, N.\& Wunder .S. (2005). Fresh trucks in the forest. Assessing incipient payment for environmental services initiatives in Bolivia. Bagor: Centre for international Forestry Research.

Russells \& Sobel (2008). The Concise encyclopedia of economics: Entrepruership $2^{\text {nd }} \mathrm{Ed}$.

Rutebemberwa, E, Pariyo .G, Peterson .S, Tomson .G \& Kallander .K. (2009). Utilisation of public or private health care providers by febrile children after user fee removal in Uganda. Malaria Journal, 8(1), 45.

School funding and equity in Rwanda report (2012). World Education Forum (2000) Education for all by 2015: Dakar frame work for Action

Smith, S.L. (2008). Athletics and Academics: Research starters.

Ssekamwa, C.J. (2000). History and development of education in Uganda. Kampala: Fountain publishers.

Tayebwa, B. M. (2007). Basic Economics (4th Ed.). Kampala: Genuine researchers \& publishers (GRP).

Tayebwa, B.M.B, (2007). Basic economics (4thed.). Kampala: GRP publishers.

Thompson, D. (2008). Extracurricular that count: Business week online (Retrieved from www.Businessweekonline.com).

UNESCO, (1999). Private education in sub-Saharan Africa: An examination of theories and concepts related to its development and finance.

Wambede \& Mukaaya (2017). Ministry closes 100 private schools. Daily Monitor, Thursday February 2nd , p. 3.

Witter, S, Dieng .T, Mbengue .D, Moreira .I, \& DeBronwere .V. (2010). The national free delivery and Caesarean policy in Senegal: Evaluating process and outcomes. Health policy and planning, 25(5), 384392.

Yates, R. (2009). Universal health care and the removal of user fees. The Lancet, 373(9680), 2078-8. 